\title{
Small-scale gill-net fisheries cause massive green turtle Chelonia mydas mortality in Baja California Sur, Mexico
}

\author{
Agnese Mancini, Volker Koch, Jeffrey A. Seminoff and Bénédicte Madon
}

\begin{abstract}
The coastal waters of Baja California Sur, Mexico, include some of the most important foraging grounds of the East Pacific green turtle Chelonia mydas. However, they are also important fishing grounds for artisanal fleets, leading potentially to high levels of bycatch mortality. We studied the impact of a small-scale gill-net fishery at San Ignacio lagoon, north-west Mexico, an important green turtle feeding ground. We conducted mortality censuses and interviewed local fishers to estimate total bycatch mortality at the lagoon. We also used marked drifters and carcasses to estimate stranding probabilities of turtles taken as bycatch. During 2006-2009 we found 262 dead turtles; $96 \%$ of the mortality occurred in May-August corresponding to the fishing season for halibut Paralichthys californicus and guitar-fish (Rhinobatus sp.). Stranding probability estimated from drifters was 0.062 (95\% confidence interval, CI, 0.035-0.094), yielding a minimum mortality of 3,516 turtles during 2006-2008 (95\% CI 2,364-6,057) or 1,172 animals per year. This is probably an underestimate of real mortality as the drifters have higher stranding probabilities than carcasses and most of the nets were set in the lower lagoon where carcasses rarely strand. Interviews with local fishers yielded a similar estimate of 1,087 (95\% CI 901-1,286) dead turtles per year. This study is emblematic of the impact of artisanal fleets on marine turtles caused by overlap of fishing and turtle feeding areas. In 2009 strandings declined by $>97 \%$, resulting from a change in fishing practices because of increased vigilance by enforcement authorities, underscoring the importance of law enforcement to protect threatened species.
\end{abstract}

Keywords Artisanal fisheries, bycatch, Chelonia mydas, East Pacific green turtle, gill-nets, mortality, marine turtles, Mexico

This paper contains supplementary material that can be found online at http://journals.cambridge.org

\footnotetext{
Agnese MANCINI ${ }^{*}$ and VolKer $\mathrm{KoCH}^{\dagger}$ (Corresponding author) Universidad Autónoma de Baja California Sur, Departamento de Biología Marina, Carretera al Sur km 5.5, 23080 La Paz, BCS, Mexico. E-mail vokoch@uabcs.mx

Jefrrey A. Seminoff NOAA-National Marine Fisheries Service, Southwest Fisheries Science Center, La Jolla, California, USA

BÉNÉDICTE MADON* School of Mathematics and Statistics, The University of New South Wales, Sydney, New South Wales, Australia

${ }^{*}$ Also at: Boomerang For Earth Conservation, Antony, France

${ }^{\dagger}$ Also at: Investigación para la Conservación y el Desarrollo, La Paz, BCS, Mexico

Received 14 July 2010. Revision requested 23 August 2010.

Accepted 25 December 2010. First published online 8 November 2011.
}

\section{Introduction}

The East Pacific green turtle Chelonia mydas occurs 1 along the west coast of the Americas from central Baja California and the Gulf of California to northern Chile and also on island groups such as the Revillagigedos and Galapagos Archipelagos (Marquez, 1990). During El Niño years green turtles may stray as far north as British Columbia and south to Chile (Marquez, 1990; Chandler, 1991; Quiñones et al., 2010). As no regional assessment exists for this stock East Pacific green turtles are included in global green turtle assessments, categorized as Endangered on the IUCN Red List (IUCN, 2010) and included in Appendix I of CITES (CITES, 2010).

The East Pacific green turtles found along the coasts of the Baja California peninsula come mainly from nesting beaches in Michoacán, the Revillagigedos Archipelago and Tres Marias Islands (Zweifel, 1960; Brattstrom, 1982; Awbrey et al., 1984; Alvarado-Diaz \& Figueroa, 1990; Marquez, 1990; NMFS-USFWS, 2007). The coastal waters of Baja California Sur include some of the most important foraging grounds for this species and our study site, San Ignacio lagoon, is among the most important (Seminoff, 2000; Gardner \& Nichols, 2001; Nichols, 2003; Seminoff et al., 2002, 2003; Koch et al., 2007; NMFS-USFWS, 2007). Because of their high primary and secondary productivity these areas are also important fishing grounds for many small-scale fisheries targeting a variety of fin- and shellfish (SAGARPA, 2007).

Bycatch, the unintentional capture of non-target species whilst fishing (Soykan et al., 2008), has become a major issue in industrial (FAO, 2004; Gilman et al., 2006; Lewison \& Crowder, 2007; Casale, 2008; Soykan et al., 2008) and artisanal fisheries (Godley et al., 1998; Lagueux, 1998; Koch et al., 2006; Peckham et al., 2007, 2008), especially because it affects long-lived, slow-growing species such as marine mammals, sea birds and turtles (Lewison et al., 2004a; Soykan et al., 2008) and has negative effects on population viability (Heppell et al., 2000). Many bycatch studies are limited by the scarcity of direct observations (Soykan et al., 2008; Tomás et al., 2008) and small spatial coverage (Lewison et al., 2004b; Soykan et al., 2008), which can only partially be solved using interviews with fishers (Carreras et al., 2004; Carranza et al., 2006; Mejuto et al. 2006).

Stranding data has been used in many studies as an index for turtle bycatch (Caillouet et al., 1996; Epperly et al., 1996; Bugoni et al., 2001; Lewison et al., 2003; Peckham 
et al., 2008; Tomás et al., 2008; Casale et al., 2010), or other mortality factors (Chaloupka et al., 2008). However, bycatch is usually underestimated because fishing gear often does not leave marks on turtles. Furthermore, strandings only represent a small percentage of real mortality and quantifying total mortality can be difficult because stranding probability depends on currents, winds and distance from shore, all of which can substantially affect the number of carcasses on a specific beach (Epperly et al., 1996; Hart et al., 2006).

Here we combined a mortality census and interviews with local fishers to estimate the impact of the artisanal guitar-fish (Rhinobatus sp.) fishery in San Ignacio, Mexico, on marine turtles. We also attempted to evaluate total at-sea mortality, using drifters to quantify stranding probabilities of dead turtles in the lagoon.

\section{Study area}

The c. 110,000 ha San Ignacio lagoon is located in the Vizcaino Biosphere Reserve on the Pacific coast of the state of Baja California Sur, Mexico. A main channel connects the lagoon to the Pacific Ocean. Tides are mixed, with an average range of $1.6 \mathrm{~m}(\mathrm{CIBNOR}, 1994)$. The lagoon is shallow with an average depth of $<3 \mathrm{~m}$ and hosts at least 85 species of algae and sea grasses (Delgadillo et al., 1992). For the purposes of this study the area was divided into three regions according to the shape and depth of the lagoon (upper, middle, lower; Fig. 1).

\section{Methods}

\section{Fisheries sector}

A total of nine cooperatives including 171 fishers (SAGARPA, 2007) and five independent fishers were officially registered in 2006 and 238 permits were expedited, of which 175 (75\%) were for fisheries outside the lagoon (SAGARPA, 2007). There are three main seasons for fishermen in the lagoon: (1) whale-watching (January-April), when no nets are allowed because grey whales Eschrichtius robustus enter the lagoon; (2) the California halibut Paralichthys californicus/ guitar-fish season (May-August), when 8-inch mesh monofilament bottom-set mesh-nets are used and checked every 24 hours; they are usually set outside the lagoon (because of permit regulations) but some illegal fishing occurs in the lagoon that has been suspected to cause high bycatch mortality of turtles; (3) lobster (Palinurus sp.) season (September-December) when lobsters are caught with box traps inside the lagoon. During the lobster season, fishers without a lobster permit usually fish outside the lagoon with nets and/or longlines or dive for pen-shells (Pinna rugosa and Atrina maura) in the lagoon.
Mortality data

From March 2006 to August 2009 mortality censuses were conducted first bimonthly (2006-2007) and then monthly (2008-2009) along a $10-\mathrm{km}$ beach $(13.5 \mathrm{~km}$ during the fishing season in June 2008 and 2009) on the eastern side of the lagoon (Fig. 1). During the main fishing season we conducted daily censuses of the beach for a total of 5, 6, 42 and 38 days in 2006, 2007, 2008 and 2009, respectively. One survey was conducted on each sampling occasion; walking the beach took 2.5-4 hours. The beach is only 5-20 m wide and dead turtles are easy to detect. Detection rate was thus close to $100 \%$ during daily censuses in June 2008-2009 but may have been less during the monthly or bimonthly census as scavengers could drag small carcasses away from the beach. We could not quantify their impact but from our observations scavengers such as coyotes Canis latrans and vultures would usually feed on the beach. We identified every carcass encountered, measured curved carapace length (CCL), recorded the location with a global positioning system and, when possible, established the cause of mortality based on examination of the carcass (Koch et al., 2006). Every dead turtle was marked with spray paint and removed from the beach to avoid double counting.

During the guitar-fish fishery in June 2008 and 2009 we conducted daily at-sea monitoring (for a total of 30 and 28 days in June 2008 and June 2009 respectively, see below). Floating turtle carcasses were hauled aboard for species identification, measuring, and to determine cause of death. When possible, carcasses were marked with a plastic tag, screwed to the shell to avoid loss, and put back in the water. Locations of release sites were recorded to see when, where, and if a carcass would strand along the monitored beach. Annual stranding rate was calculated as the number of dead turtles per kilometre of monitored beach per year assuming a detection probability of $99 \%$ of carcasses on the beach for the entire study period.

\section{Fishing effort}

During the at-sea monitoring in June 2008 and June 2009 (see above) we monitored daily fishing effort in the lagoon from a small skiff with outboard motor. The survey was from the top to the mouth of the lagoon, usually passing along the central channel. When a halibut net was spotted (illegal inside lagoons in Mexico), we recorded its position, measured the total length and checked the number of entangled turtles. Fishing effort was calculated as the total length of nets per day. When the total length of a net was not available, as fishermen sometimes only have a buoy on one end of the net, we used mean length of the observed nets. Density of nets was calculated using a Kernel density estimator to highlight high-use areas within the lagoon (Worton, 1989). The bottom-set nets are checked only every 


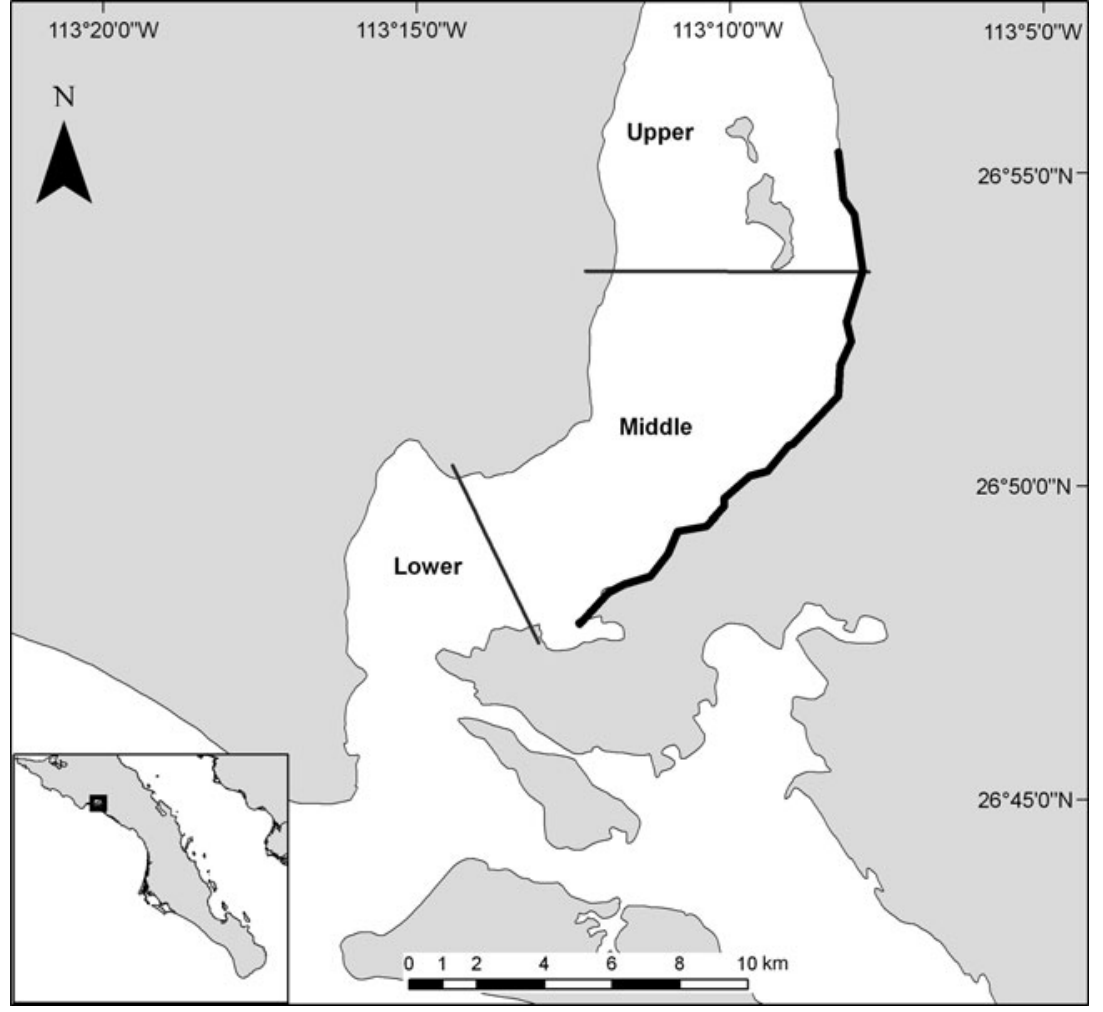

FIG. 1 The study area in the San Ignacio Lagoon in the Vizcaino Biosphere Reserve, indicating the $14 \mathrm{~km}$ of beach that was monitored during 2006-2008 (thick black line) and the division of the lagoon into upper, middle and lower regions. The inset indicates the location of the main map on the Pacific coast of the state of Baja California Sur, Mexico.
24 hours and therefore the mortality rate for captured turtles is close to $100 \%$ because turtles cannot survive being entangled for longer than c. 60 minutes. As a result all turtles we found in the nets during these surveys were dead.

\section{Interviews}

From March 2006 to July 2008, 22 semi-structured interviews were carried out at five fishing camps (13\% of regular fishers operating in the area; SAGARPA, 2007) along the east side of the lagoon. The interviews were to gather quantitative and qualitative data on fishing practices inside the lagoon and interactions between fisheries and turtles. Participants were chosen opportunistically and interviewed separately to avoid collecting group opinions (Janis, 1972). Before each interview the purpose of the study was explained to each participant and anonymity was granted. Control questions were used to verify the consistency of the information obtained (for further details see Mancini \& Koch, 2009). If not otherwise specified, turtles caught in nets were all dead; no fisher mentioned releasing live turtles.

\section{Exploratory analysis: stranding probabilities and rates}

In an attempt to estimate total at-sea mortality of green turtles we conducted a pilot study using marked drifters (oranges) during June 2008 and June 2009. Oranges float in the water column similarly to turtles, are not affected much by the wind and follow surface currents (Muhlin et al.,
2008). Marked oranges were released from the top to the mouth of the lagoon along a transect in the central channel where most of the fishing occurred. We monitored the beach to detect stranded drifters from day 1 after deployment until we didn't find stranded drifters for two consecutive days (day 7). As stranding rates can vary depending on the currents in the lagoon we deployed drifters during tidal conditions similar to those when the fishing occurred, usually 2-3 days around quarter moon tides. Drifter stranding rate was calculated as the total number of recovered drifters/total number of released drifters. We then estimated the stranding probability of carcasses that were found floating in the lagoon as a linear function of drifter stranding probability, including the following assumptions: (1) despite their different size and shape, turtle carcasses and drifters follow surface currents in a similar way; (2) oranges are likely to strand faster as they do not sink for a certain time as turtle carcasses do; (3) we considered a detection probability of $95 \%$ for oranges (high visibility because of their bright colour but a small probability that they become buried under sea-grass) and 99\% for turtles (because of their larger size).

Assuming that the stranding probability of dead turtles was normally distributed, the overall regression model was:

$$
\hat{p}_{\text {turtle }}=\beta \times \hat{p}_{\text {drifter }}+\varepsilon
$$

where $\hat{p}_{\text {turtle }}$ and $\hat{p}_{\text {drifter }}$ are $12 \times 1$ vectors of stranding probabilities of dead turtles and drifters, respectively, $\beta$ the 
regression coefficient associated with the probability of stranding of drifters and $\varepsilon$ an independent random variable (Appendix 1). A confidence interval for the stranding probability of dead turtles was computed via parametric bootstrapping: the original vector of stranding probabilities of drifters was re-sampled 1,00o times by randomly sampling from the original dataset and the mean was calculated for each new vector obtained. The 25 th and 975 th largest values were used to obtain the bounds of a $95 \%$ bootstrapped confidence interval (Davis \& Hinkley, 1997).

\section{Total mortality estimates}

Total bycatch mortality was estimated from data on strandings and information collected through interviews. The actual number of dead turtles from stranding observations was estimated using:

$$
\hat{N}_{\text {dead turtles }}=\frac{n}{\hat{p}_{\text {turtle }}}
$$

where $n$ was the number of dead turtles found on the beach during the study period. A confidence interval for the number of dead turtles was again computed via parametric bootstrapping: we randomly sampled the confidence interval for the stranding probability of dead turtles and used the sampled value to obtain the number of dead turtles. Confidence intervals were obtained as described above. Parametric bootstrapping was also used to compute the confidence interval of dead turtles reported by fishers during the interviews: reported numbers of dead turtles were randomly sampled 1,000 times to obtain a corrected $95 \%$ confidence interval as described above.

\section{Results}

\section{Turtle mortality}

From March 2006 to August 2009 (42 months) we found 262 dead turtles in San Ignacio Lagoon, 261 green turtles and one hawksbill turtle Eretmochelys imbricata: 84\% $(\mathrm{n}=220)$ were found stranded on the beach and $16 \%$ $(n=42)$ were observed at sea (Table 1$)$. Mean stranding rate was 5.03 turtles $\mathrm{km}^{-1}$ year ${ }^{-1}$. Ninety-six percent of total mortality was recorded between May and August (with a peak of $65 \%$ of mortality during June). In 2009 the number of dead turtles declined sharply, with only two strandings.

CCL of dead turtles was $39.7-105.4 \mathrm{~cm}(\mathrm{n}=211$; mean $=59.52 \pm S D$ 11.29; Fig. 2). Using the mean nesting size of $82 \mathrm{~cm}$ CCL (Alvarado-Diaz \& Figueroa, 1990) we estimated that $94 \%$ of the turtles were juveniles. In $84 \%$ of the cases external examination of the carcasses did not reveal any apparent cause of mortality and advanced decomposition and scavengers did not allow us to conduct a necropsy. In $16 \%$ of the cases death was attributed to fisheries because marks of nets on the flippers and neck of fresh carcasses were present. In the only net we could check we found seven dead turtles entangled. Lateral cuts between carapace and plastron, made by fishers to make the carcass sink, were also observed on several occasions. Necropsies were conducted on 10 fresh carcasses: all presented full stomachs, suggesting that the turtles were healthy and feeding normally, but we found fluid and blood in lungs and net marks on neck and front flippers, suggesting drowning (M.L. Parga, pers. comm.). We tagged 25 carcasses encountered at sea, of which only two stranded on the monitored beach (8\%) 1 and 5 days later.

\section{Fishing effort}

Nets were present in the lagoon during 15-18 June 2008 and we counted 36 nets in total: 14 nets on day 1 , decreasing to two nets on day 4. From day 5 onwards no nets were found within the lagoon as the tides were strong. The length of 26 nets was $138-1,000 \mathrm{~m}$ (mean $=415 \pm \mathrm{SE} 194 \mathrm{~m})$. We estimate that the total net length deployed in the lagoon was $14,951 \mathrm{~m}$, of which $3 \%$ (total length $415 \mathrm{~m}$ ) were found in the upper, $31 \%$ (total length $4,659 \mathrm{~m}$ ) in the middle and $66 \%$ (total length 9,877 m) in the lower lagoon (Fig. 3). The kernel density estimator highlighted the presence of at least two high-use areas, a large one in the low region and a small one in the middle region. During daily censuses in June 2009 no nets were observed inside the lagoon.

\section{Interviews}

Interviewees reported that at least 15 boats per day used gill-nets inside the lagoon during the summer months of 2006-2008. This fishery usually lasted 7-15 days and was considered by all interviewees to be responsible for the high bycatch mortality. They reported an average of seven turtles per day per boat drowned in the nets; one fisher reported the capture of 22 turtles in 1 day. Interviewees reported that guitar-fish catches are high when gravid females enter the lagoon to give birth, and the economic benefits outweigh the risk of getting caught.

\section{Stranding probabilities}

Stranding probabilities of drifters decreased, because of the currents, from the upper to lower lagoon ( $48 \%$ in the upper, $15 \%$ in the middle and $0 \%$ in the lower lagoon; Fig. 3), However, as only two of our marked carcasses stranded we could not include differential stranding probabilities for different parts of the lagoon and had to assume a constant value. The model constructed from the data (Appendix 1) considered only the effect of the stranding probability of 
TABLE 1 Dead turtles observed per month (with number of floating carcasses in parentheses) during 2006-2009. Blank cells indicate the absence of a survey. Stranding rates are calculated based only on stranded carcasses observed.

\begin{tabular}{|c|c|c|c|c|c|c|}
\hline & 2006 & 2007 & 2008 & 2009 & Total (\%) & $\%$ strandings \\
\hline Jan. & & & & 0 & $0(0.0)$ & 0.0 \\
\hline Feb. & & 1 & 0 & & $1(0.4)$ & 0.5 \\
\hline Mar. & $2(1)$ & & & & $2(0.8)$ & 0.5 \\
\hline Apr. & & 1 & 1 & 0 & $2(0.8)$ & 0.9 \\
\hline May & 3 & & 0 & 0 & $3(1.1)$ & 1.4 \\
\hline June & & 73 & $110(41)$ & 1 & $184(70.2)$ & 65.0 \\
\hline July & 39 & 10 & 0 & 1 & $50(19.1)$ & 22.7 \\
\hline Aug. & 4 & 11 & 1 & 0 & $16(6.1)$ & 7.3 \\
\hline Sep. & & & 0 & & $0(0.0)$ & 0.0 \\
\hline Oct. & 0 & 0 & 0 & & $0(0.0)$ & 0.0 \\
\hline Nov. & & & & & $0(0.0)$ & 0.0 \\
\hline Dec. & 4 & & & & $4(1.5)$ & 1.8 \\
\hline Total & $52(1)$ & 96 & $112(41)$ & 2 & $262(42)$ & \\
\hline Annual stranding rate (turtles $\mathrm{km}^{-1}$ ) & 5.2 & 9.6 & 5.3 & 0.2 & 5.1 & \\
\hline Number of daily surveys & 5 & 6 & 42 & 38 & & \\
\hline
\end{tabular}

drifters as in equation $(1)\left(\mathrm{R}^{2}=0.59, \mathrm{~F}_{1,0.05}^{10}=14.3, \mathrm{P}<0.005\right)$ with

$$
\hat{p}_{\text {turtle }_{i}}=0.1299-0.215 \times \hat{p}_{\text {drifter }_{i}}
$$

Using this model and an estimated $\hat{p}_{\text {drifter }}$ of 0.32 (61 drifters stranded of the 192 released) we predicted a stranding probability for dead turtles of 0.062 ( $95 \%$ confidence interval, CI, 0.035-0.094).

\section{Total mortality estimates}

Two hundred and twenty dead turtles were found on the beach during 2006-2009, giving an estimated number of dead turtles (using the stranding probability from the drifters) during the study period of 3,548 (95\% CI 2,3765,976). From 2006-2008, when guitar-fish were caught with

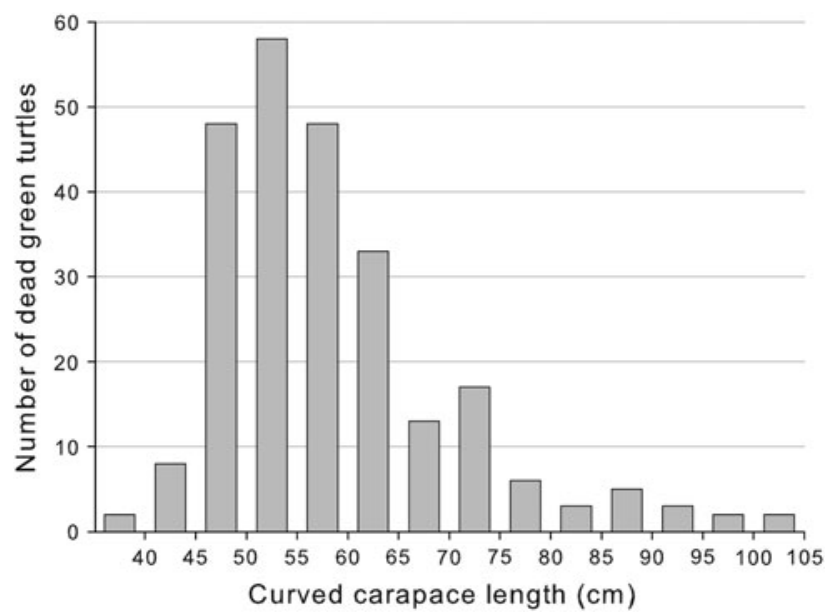

FIG. 2 Size distribution of East Pacific green turtles Chelonia mydas found dead at San Ignacio Lagoon during 2006-2009. set-nets that were left for 24 hours, total mortality was estimated to be 3,516 turtles (95\% CI 2,364-6,057) based on our extrapolations, or 1,172 turtles per year. In 2009, when guitar-fish were caught with drift-nets, the average death count dropped sharply to only 32 turtles (95\% CI 22-54; Table 2), a reduction of $97 \%$. Bootstrapped data from interviews resulted in a mean mortality of 1,087 turtles per fishing season (95\% CI 901-1,286; Appendix 2).

\section{Discussion}

To our knowledge this study is the first attempt to estimate total bycatch mortality of marine turtles using interviews with fishermen and stranding data independently, combined with estimates of the probability of stranding using data from both marked drifters and carcasses. However, there are some caveats to our methodology: (1) drifter devices are smaller and lighter than turtles, (2) they float all the time instead of initially sinking, as turtles do, until decomposition starts to produce gas, (3) the small number of recovered carcasses did not allow us to estimate a stranding probability as a function of the region where the animal was released. Nevertheless, our methodology will most likely underestimate total mortality and thus our estimates should be considered minimum values. Additionally, we only considered turtles stranded at the monitored beach in our estimate of total mortality in the lagoon. The total length of beach where dead turtles regularly strand is more than twice as long as the section monitored, thus leading to a further underestimate of total mortality.

For any similar future studies of stranding some improvements to our methodology would be beneficial: (1) deploy 20-30 drifters with each floating carcass to compare directly their behaviour and increase the strength of the stranding probability function, (2) monitor floating carcasses and 


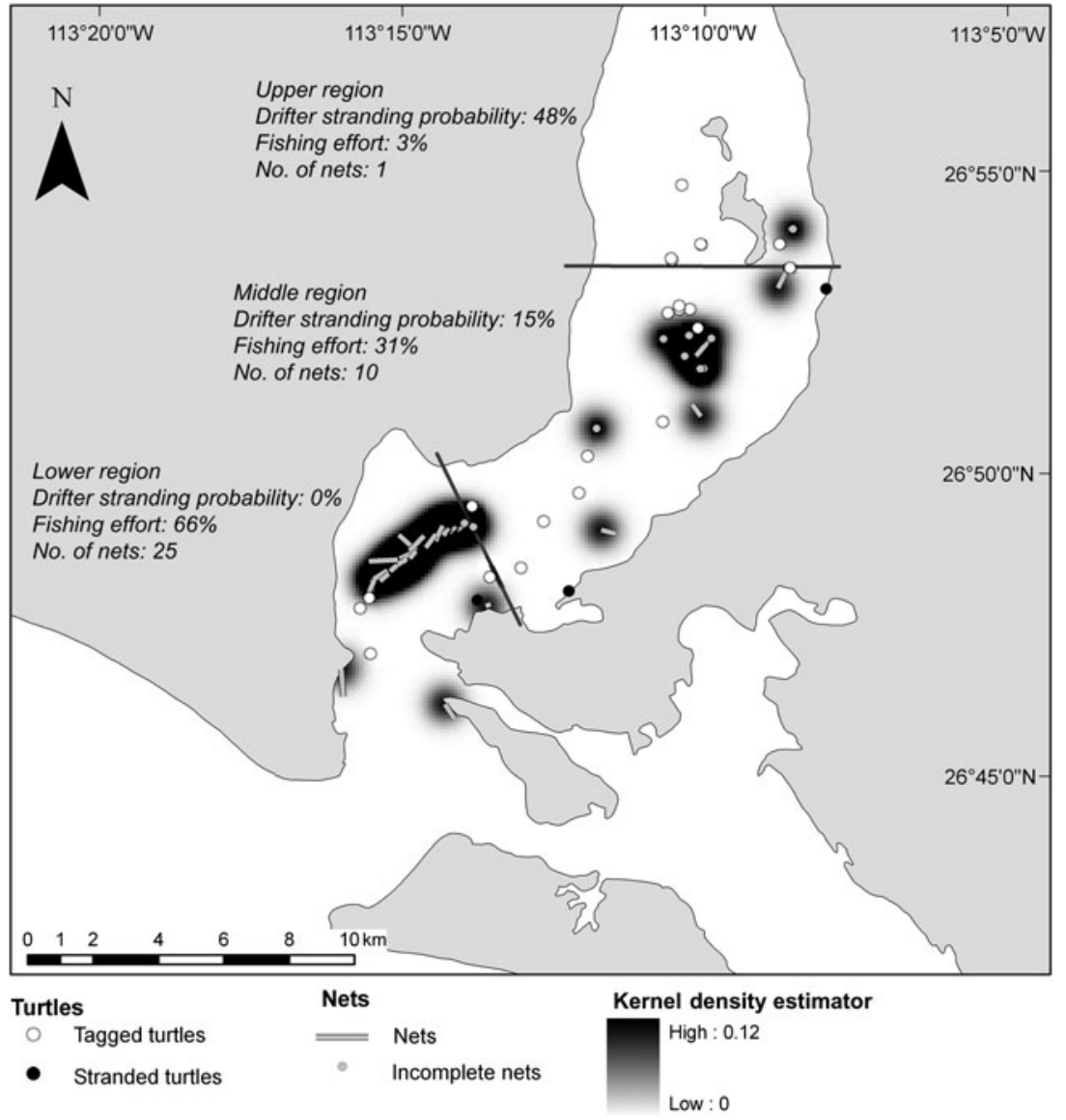

FIG. 3 Location of the gill-nets encountered in San Ignacio Lagoon in June 2008, with the stranding probability of drifters, fishing effort and percentage of nets for the three regions. A kernel density estimator for the distribution of bottom-set meshnets identifies the areas of high risk for turtles. drifters for extensive periods (up to 15 days) during months of high mortality, if possible including VHF or GPS telemetry (Senko et al., 2010b), (3) conduct a stranding census twice per day to measure detection rate for both drifters and turtle carcasses, and (4) follow stranded carcasses over extended periods of time to see if they are being moved by scavengers or by tides.

Annual mortality estimates (1,172 turtles per year during 2006-2008) from 220 individuals observed stranded and estimated probabilities of stranding were similar to estimates obtained from interviews with fishers $(1,087$ turtles per fishing season). As with our estimate from stranded carcasses, the bycatch rate calculated from interviews is probably a minimum estimate. As marine turtles are protected by Mexican law (DOF, 1990) fishers may tend to report lower numbers taken as bycatch to protect themselves and avoid stricter law enforcement in the area. Thus, while the two estimates are close both tend to underestimate total mortality, albeit for different reasons.

Comparing stranding rates can be difficult because of differences in monitoring effort and stranding probability at individual beaches (Peckham et al., 2008). However, the annual stranding rate reported for San Ignacio Lagoon (5.81 turtles $\mathrm{km}^{-1}$ ) is one of the highest reported (Chaloupka et al., 2008; Peckham et al., 2008). During June 2006-2008, when $65 \%$ of the strandings occurred, mean stranding rate

TABLE 2 Estimates of total turtle mortality from stranding data using a constant stranding probability $(\mathrm{P}=0.062$, see text for details) estimated from drifters and strandings of carcasses.

\begin{tabular}{llrr}
\hline & $\begin{array}{l}\text { No. of } \\
\text { stranded turtles }\end{array}$ & $\begin{array}{l}\text { Estimate of annual } \\
\text { total mortality }\end{array}$ & $95 \%$ CI \\
\hline 2006 & 51 & 822 & $550-1,410$ \\
2007 & 96 & 1,548 & $1,037-2,622$ \\
2008 & 71 & 1,145 & $766-1,943$ \\
2009 & 2 & 32 & $22-54$ \\
Annual mean 2006-2008 & & 1,172 & $784-1,992$ \\
Total 2006-2008 & & 3,516 & $2,364-6,057$ \\
\hline
\end{tabular}


rose to 8.49 turtles $\mathrm{km}^{-1}$, comparable to mass strandings in India with 18.6 olive-ridley turtles Lepidochelys olivacea $\mathrm{km}^{-1}$ (Shanker et al., 2004), and in Magdalena Bay, Baja California Sur, with 10.8 loggerhead turtles Caretta caretta $\mathrm{km}^{-1}$ (Peckham et al., 2008) during summer months.

Even if only $16 \%$ of deaths were attributed directly to fisheries the relationship between massive mortality and bycatch is evident and well supported by results from interviews, censuses and observations of the fishery. Eightinch mesh-nets are banned within lagoons and estuaries by Mexican law (DOF, 2001). However, because of the lack of enforcement some fishers use these nets within the lagoon to catch guitar-fish and halibut. The main cause of turtle mortality in gill-nets is drowning from forced apnea (Casale, 2008). Forced submergence of $<10$ minutes produces a mortality rate of c. $1 \%$ in trawl nets but mortality rate increases to $50-100 \%$ for submergence times $\geq 60$ minutes (Sasso \& Epperly, 2006). Nets are set in the morning in the lagoon and checked 24 hours later (R. Mayoral, pers. comm.), resulting in almost $100 \%$ mortality for entangled turtles, which cannot surface to breathe as the nets are heavily weighed and anchored on the bottom. The use of drifting nets in 2009 that were checked approximately every 30 minutes explains the drop in bycatch mortality and stranding rates in that year. East Pacific green turtles in San Ignacio Lagoon have a preference for shallow to moderate water depths during the night and for sea-grass areas by day (Senko et al., 2010a). Furthermore, tidally-oriented movements occur in green turtles in other feeding areas (Brooks et al., 2009). Sixty-one percent of gill-nets deployed in the lagoon were located in the lower region characterized by moderately deep water, patches of sea-grass and strong tidal currents, suggesting that the risk for turtles of becoming entangled is high in this area.

East Pacific green turtles in San Ignacio Lagoon include individuals from the Revillagigedos breeding stock (Nichols, 2003; P. Dutton, unpubl. data), which is composed of $<100$ nesting females each year (NMFS-USFWS, 2007). Recent studies have shown that East Pacific green turtles present high site fidelity, with low connectivity between foraging grounds (Lopez-Castro et al., 2010; Senko et al., 2010a,b) and spend extended periods in the same area (Seminoff et al., 2003). Considering that the illegal guitar-fish fishery has existed in the lagoon for at least 5 years (R. Mayoral, pers. comm.), a mean annual mortality of 1,172 turtles could represent a total mortality of almost 6,000 individuals. Such a figure could have affected the genetic diversity of the East Pacific green turtle, which is fundamental for preserving the species' resilience to respond to environmental change (Bowen \& Karl, 1997).

In summer 2009 authorities began a weekly patrol and obliged fishers not to anchor their nets and to check them every 30 minutes, resulting in a $97 \%$ decline in turtle strandings. However, other studies in the region have also documented high turtle mortality from bycatch and illegal take (Gardner \& Nichols, 2001; Koch et al., 2006; Peckham et al., 2007, 2008; Mancini \& Koch, 2009) and Nichols (2003) estimated total mortalities of up to 30,00o turtles per year on the Baja peninsula (direct take for consumption and bycatch). Currently we are compiling the available data from all of north-west Mexico. Preliminary results indicate that the situation with illegal take in the states of Sinaloa and Sonora may be similar to or worse than in Baja California Sur (V. Koch et al., unpubl. data.). There is almost no information available from other parts of Mexico and thus we do not know what impact fisheries have on turtles elsewhere in the country.

San Ignacio Lagoon is emblematic of the potential impact of small-scale fisheries on marine turtle populations. The global death-toll of turtles and other threatened megafauna from unregulated artisanal fisheries in coastal zones is probably high. Ninety-nine percent of 5.1 million fishers globally are employed in small-scale fisheries and $90 \%$ of total captures occur in the coastal zone (FAO, 1999). Most of these fisheries are poorly regulated and little is known about bycatch levels and/or illegal take. Further efforts to collect bycatch data from artisanal fleets is clearly needed, as there are several examples showing that their impact on threatened turtles is comparable to, or surpasses, that of industrial fisheries (Godley et al., 1998; Lagueux, 1998; Koch et al., 2006; Peckham et al., 2007, 2008; Tomás et al., 2008).

The situation in San Ignacio Lagoon has improved substantially. During the 2010 summer fishing season turtle mortality was also exceptionally low because of the presence of enforcement authorities and, consequently, lack of illegal exploitation of guitar-fish. However, information from members of the fishing community suggests that a small group of fishermen would resume their former fishing habits if vigilance should slack, and thus the problem has only been solved temporarily.

\section{Acknowledgements}

We thank the Secretaría para el Medio Ambiente y los Recursos Naturales (SEMARNAT) for providing the permits under which this study was conducted (SGPA/DGVS/ 03846, SGPA/DGVS/03944/07, SGPA/DGVS/03816/08, SGPA/DGVS/05603/09). This study was funded by Consejo Nacional de Ciencias y Tecnologias grant SEMARNAT-2004-C01-277 and by the Earthwatch foundation. We thank all the volunteers, fishers and members of the Grupo Tortuguero who supported our project. AM was supported by Rufford Small Grants for Conservation.

\section{References}

Alvarado-Diaz, J. \& Figueroa, A. (1990) The Ecological Recovery of Sea Turtles of Michoacan, Mexico. Special Attention: The Black 
Turtle, Chelonia agassizii. Final report 1989-1990. Submitted to US Fish and Widlife Service and WWF-US, Washington, DC, USA.

Awbrey, F.T., Leatherwood, S., Mitchell, E.D. \& Rogers, W. (1984) Nesting green sea turtles (Chelonia mydas) on Isla Clarión, Islas Revillagigedos, México. Bulletin of the Southern Californian Academy of Science, 82, 89-75.

Bowen, B.W. \& KarL, S.A. (1997) Population genetics, phylogeny, and molecular evolution. In The Biology of Sea Turtles (eds P.L. Lutz \& J.A. Musick), pp. 29-50. CRC Press, Boca Raton, USA.

Brattstrom, B.H. (1982) Breeding of the green turtle, Chelonia mydas, on the Islas Revillagigedo, México. Herpetological Review, $13,71$.

Brooks, L.B., Harvey, J.T. \& Nichols, W.J. (2009) Tidal movements of East Pacific green turtle Chelonia mydas at a foraging area in Baja California Sur, México. Marine Ecology Progress Series, 386, 263-274.

Bugoni, L., Krause, L. \& Petry, M.V. (2001) Marine debris and human impacts on sea turtles in southern Brazil. Marine Pollution Bulletin, 42, 1330-1334.

Caillouet, C.W., Shaver, D.J., Teas, W.G., Nance, J.M., Revera, D.B. \& Cannon, A.C. (1996) Relationship between sea turtle stranding rates and shrimp fishing intensities in the northwestern Gulf of Mexico: 1986-1989 versus 1990-1993. Fishery Bulletin, 94, 237-249.

Carranza, A., Domingo, A. \& Estrades, A. (2006) Pelagic longlines: a threat to sea turtles in the Equatorial Eastern Atlantic. Biological Conservation, 131, 52-57.

Carreras, C., Cardona, L. \& A guilar, A. (2004) Incidental catch of the loggerhead turtle Caretta caretta off the Balearic Islands (western Mediterranean). Biological Conservation, 117, 321-329.

Casale, P. (2008) Incidental Catch of Marine Turtles in the Mediterranean Sea: Captures, Mortality, Priorities. WWF, Rome, Italy.

Casale, P., Affronte, M., Isacco, G., Freggi, D., Vallini, C., D'Astore, P.P. et al. (2010) Sea turtle strandings reveal high anthropogenic mortality in Italian waters. Aquatic Conservation: Marine and Freshwater Ecosystems, 20, 611-620.

Chaloupka, M., Work, T.M., Balazs, G.H., Murakawa, S.K. \& Morris, R. (2008) Cause-specific temporal and spatial trends in green sea turtles in the Hawaiian Archipelago (1982-2003). Marine Biology, 154, 887-898.

Chandler, M. (1991) New records of marine turtles in Chile. Marine Turtle Newsletter, 52, 8-11.

CibNOR (Centro de Investigación Biologica del Noroeste) (1994) Manifestación de Impacto Ambiental Modalidad Intermedia: Proyecto "Salitrales de San Ignacio". Part II. CIBNOR, La Paz, Mexico.

CITES (2010) Convention on International Trade in Endangered Species of Wild Fauna and Flora. Http://www.cites.org [accessed 12 February 2010].

Davis, A.C. \& Hinkley, D.V. (1997) Bootstrap Methods and Their Application. Cambridge University Press, Cambridge, UK.

Delgadillo, J., Peinado, M., De la Cruz, M., MartinezParras, J.M., Alcaraz, F. \& De la Torre, A. (1992) Analisis fitosociologico de los saladares y manglares de Baja California, México. Acta Botánica Mexicana, 19, 1-35.

DOF (Diario Oficial de la Federación) (1990) Acuerdo que establece veda para todas las especies y subespecies de tortugas marinas en aguas de jurisdicción nacional de los litorales del Océano Pacífico, Golfo de México y Mar Caribe. Diario Oficial de la Federación, Mexico City, México, 31 May, pp. 21-22.

DOF (Diario Oficial de la Federación) (2001) Ley de Pesca. Diario Oficial de la Federación, Mexico City, Mexico, 25 June, pp. 1-14.
Epperly, S.P., Braun, J., Chester, A.J., Cross, F.A., Merriner, J.V., Tester, P.A. \& ChurChill, J.H. (1996) Beach strandings as an indicator of at-sea mortality of sea turtles. Bulletin of Marine Science, 59, 289-297.

FAO (Food and Agriculture Organization) (1999) Guidelines for the Routine Collection of Capture Fishery Data. FAO Fisheries Technical Paper No. 382. FAO, Rome, Italy.

FAO (Food and Agriculture Organization) (2004) Expert Consultation on Interactions Between Sea Turtles and Fisheries within an Ecosystem Context. FAO Fisheries Report No. 738. FAO, Rome, Italy.

Gardner, S.C. \& Nichols, W.J. (2001) Assessment of sea turtle mortality rates in the Bahia Magdalena region, BCS, Mexico. Chelonian Conservation and Biology, 4, 197-199.

Gilman, E., Zollett, E., Beverly, S., Nakano, H., Davis, K., Shiode, D. et al. (2006) Reducing sea turtle by-catch in pelagic longline fisheries. Fish and Fisheries, 7, 2-23.

Godley, B.J., Gücü, A.C. \& Broderick, A.C. (1998) Interaction between marine turtles and artisanal fisheries in the eastern Mediterranean: a probable cause for concern? Zoology in the Middle East, 16, 49-84.

Hart, K.M., Mooreside, P. \& Crowder, L.B. (2006) Interpreting the spatio-temporal patterns of sea turtle strandings: going with the flow. Biological Conservation, 129, 283-290.

Heppell, S.S., Caswell, H. \& Crowder, L.B. (2000) Life histories and elasticity patterns: perturbation analysis for species with minimal demographic data. Ecology, 81, 654-665.

IUCN (2010) IUCN Red List of Threatened Species. Http:// www.iucnredlist.org/ [accessed 12 February 2010].

Ja Nis, I.L. (1972) Victims of Groupthink. Houghton-Mifflin, Boston, USA.

Koch, V., Brook, L.B. \& Nichols, W.J. (2007) Population ecology of the green/black turtle (Chelonia mydas) in Bahía Magdalena, Mexico. Marine Biology, 153, 35-46.

Koch, V., Nichols, W.J., Peскham, H. \& de la Toba, V. (2006) Estimates of sea turtle mortality from poaching and bycatch in Bahía Magdalena, Baja California Sur, Mexico. Biological Conservation, $128,327-334$.

Lagueux, C. (1998) Marine turtle fishery of Caribbean Nicaragua: human use patterns and harvest trends. $\mathrm{PhD}$ thesis, University of Florida, Gainsville, USA.

Lewison, R.L. \& Crowder, L.B. (2007) Putting longline bycatch of sea turtles into perspective. Conservation Biology, 21, 79-86.

Lewison, R.L., Crowder, L.B., Read, A.J. \& Freeman, S.A. (2004b) Understanding impacts of fisheries bycatch on marine megafauna. Trends in Ecology \& Evolution, 19, 598-604.

Lewison, R.L., Crowder, L.B. \& Shaver, D.J. (2003) The impact of turtle excluder devices and fisheries closures on loggerhead and Kemp's ridley strandings in the western Gulf of Mexico. Conservation Biology, 17, 1089-1097.

Lewison, R.L., Freeman, S.A. \& Crowder, L.B. (2004a) Quantifying the effects of fisheries on threatened species: the impact of pelagic longlines on loggerhead and leatherback sea turtles. Ecology Letters, 7, 221-231.

López-Castro, M.C., Koch, V., Mariscal-Loza, A. \& Nichols, W.J. (2010) Long-term monitoring of black turtles Chelonia mydas at coastal foraging areas off the Baja California Peninsula. Endangered Species Research, 11, 35-45.

Mancini, A. \& Koch, V. (2009) Sea turtle consumption and black market trade in Baja California Sur, Mexico. Endangered Species Research, 7, 1-10.

Marquez, R. (1990) Sea Turtles of the World. An Annotated and Illustrated Catalogue of Sea Turtle Species Known to Date. Food and Agriculture Organization Species Catalogue, FAO, Rome, Italy. 
Mejuto, J., De la Serna, J.M., Valeiras, J. \& Camiñas, J.A. (2006) Actuaciones en el marco de proyectos de investigación relacionadas con el estudio de las interacciones entre las pesquerías de túnidos y especies afines y las tortugas marinas. Instituto Español de Oceanografía, Malaga, Spain. Http://www.marm. es/es/pesca/temas/espacios-y-especies-marinas-protegidas/ proyecto_ieo_tcm7-7357.pdf [accessed 12 February 2011].

Muhlin, J.F., Engel, C.R., Stessel, R., Weatherbee, R.A. \& BRAWLEY, S.H. (2008) The influence of coastal topography, circulation patterns, and rafting in structuring populations of an intertidal alga. Molecular Ecology, 17, 1198-1210.

Nichols, W.J. (2003) Biology and conservation of sea turtles in Baja California, Mexico. PhD thesis, University of Arizona, Tucson, USA.

NMFS-USFWS (National Marine Fisheries Service-U.S. Fish and Wildlife Service) (2007) Green Turtle (Chelonia mydas) 5-year review: Summary and Evaluation. National Marine Fisheries Service, Silver Spring, USA.

Peckham, S.H., Diaz, D.M., Walli, A., Ruiz, G., Crowder, L.B. \& Nichols, W.J. (2007) Small-scale fisheries bycatch jeopardizes endangered pacific loggerhead turtles. PLoS ONE, 2(10), e1041.

Peckham, S.H., Maldonado-Diaz, D., Koch, V., Mancini, A., Gaos, A., Tinker, M.T. \& Nichols, W.J. (2008) High mortality of loggerhead turtles due to bycatch, human consumption and strandings at Baja California Sur, Mexico, 2003 to 2007. Endangered Species Research, 5, 171-183.

Quiñones, J., Gonzalez Carmen, V., Zeballos, J., Purca, S. \& ManZan, H. (2010) Effects of El Niño-driven environmental variability on black turtle migration to Peruvian foraging grounds. Hydrobiologia, 645, 69-79.

Sagarpa (Secretaria de Agricultura, Ganadería, Desarrollo rural, Pesca y Alimentación) (2007) Anuario estadistico de pesca: Permisionarios de embarcaciones menores y mayores. CONAPESCA, Mazatlán, Mexico.

SASSO, C.R. \& EPPERLY, S.P. (2006) Seasonal sea turtle mortality risk from forced submergence in bottom trawls. Fisheries Research, 81, $86-88$.

Seminoff, J.A. (2000) Biology of the East Pacific green turtle, Chelonia mydas agassizii at a warm temperate feeding area in the Gulf of California, Mexico. PhD thesis, University of Arizona, Tucson, USA.

Seminoff, J.A., Jones, T.T., Resendiz, A., Nichols, W.J. \& Chaloupka, M.Y. (2003) Monitoring green turtles (Chelonia mydas) at a coastal foraging area in Baja California, Mexico: multiple indices describe population status. Journal of the Marine Biological Association of the UK, 83, 1355-1362.

Seminoff, J.A., Resendiz, A. \& Nichols, W.J. (2002) Home range of the East Pacific green turtle, Chelonia mydas at a coastal foraging ground in the Gulf of California, Mexico. Marine Ecology Progress Series, 242, 253-265.
Senko, J., Koch, V., Megill, W., Carthy, R.M., Templeton, R. \& Nichols, W.J. (2010a) Fine-scale daily movement patterns and habitat use of an endangered marine megaherbivore at a shallow coastal lagoon. Journal of Experimental Marine Biology and Ecology, 391, 92-100.

Senko, J., Lopez-Castro, M., Koch, V. \& Nichols, W.J. (2010b) Immature East Pacific green turtles (Chelonia mydas) use multiple foraging areas off the Pacific Coast of Baja California Sur, Mexico: first evidence from mark-recapture data. Pacific Science, 64, 125130.

Shanker, K., Pandav, B. \& Choudhury, B.C. (2004) An assessment of the olive ridley turtle nesting population in Orissa, India. Biological Conservation, 115, 149-160.

Soykan, C.U., Moore, J.E., Zydelis, R., Crowder, L.B., Safina, C. \& LEWISON, R.L. (2008) Why study bycatch? An introduction to the Theme Section on fisheries bycatch. Endangered Species Research, 5, 91-102.

Tomás, J., Gozalbes, P., Raga, J.A. \& Godley, B.J. (2008) Bycatch of loggerhead sea turtles: insights from 14 years of stranding data. Endangered Species Research, 5, 167-169.

Worton, B.J. (1989) Kernel methods for estimating the utilization distribution in home-range studies. Ecology, 70, 164-168.

Zweifel, R.G. (1960) Results of the Puritan American Museum of Natural History expedition in north-western Mexico. Bulletin of the American Museum of Natural History, 119, 60.

\section{Appendices 1-2}

The appendices for this article are available online at http:// journals.cambridge.org

\section{Biographical sketches}

Agnese Mancini is studying marine turtles in South-East Asia, Pacific Mexico and the Red Sea, with research interests in behavioural ecology and interactions with local fisheries. VOLKER KOCH is studying the population ecology of marine species, energy flow and ecosystem modelling, mollusc aquaculture and marine turtle conservation in Latin America. Jeffrey Seminoff is a member of the IUCN Marine Turtle Specialist Group and is involved in updating marine turtle status assessments for the US Endangered Species Act. His research uses innovative approaches such as stable isotope analyses, bio-telemetry, animal-borne imagery and aerial surveys to elucidate the life history of marine turtles throughout the Pacific Ocean. BÉnédicte Madon's research focuses on new models to estimate animal population size, especially of humpback whale populations. Her interests include ecological statistics, modelling and population management and conservation. 